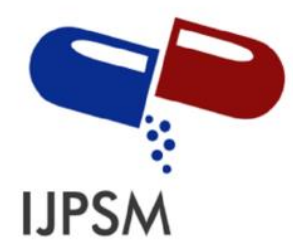

Sakshi Ahirwar et al, Int. Journal of Pharmaceutical Sciences and Medicine (IJPSM), Vol.6 Issue. 8, August- 2021, pg. 78-103

ISSN: 2519-9889

Impact Factor: 3.426

\title{
Drugs Used During Pregnancy and Lactation
}

\author{
Sakshi Ahirwar; Saloni Chourasia; Bhagyashree Mahajan \\ Swami Vivekanand College of Pharmacy \\ DOI: 10.47760/ijpsm.2021.v06i08.006
}

\begin{abstract}
In time of pregnancy, drugs are often required to treat certain disorders. In general potential benefit outweighs known risks, drugs may be considered for treatment of disorders during pregnancy. All maternal drugs not cross the planceta to the fetus. Some drugs that cross the placenta may have a direct toxic effect or teratogenic effect. Understanding the risks of drugs use in pregnancy has lagged being the advances in other areas of pharmacotherapy. The adverse developmental effects of pharmaceutical products are recognized to include not only mal formation, but also growth restrictions, fetal death and functional defects in the newborn.

Drug that does not cross placenta but still harm the fortus. 1979, FDA developed a system determining teratogenic risk of drugs based on animals\& human studies. Divided drugs into 5 categories (A , B , C, D, X). This article provide clinical therapeutic guidance relating drug use in pregnancy.
\end{abstract}

KEYWORDS: Pregnancy, teretogenicity, miscarriage, medication, herbal drugs, lactation.

\section{INTRODUCTION}

Most prescribers and users of drugs are familiar with the precautions given concerning drug use this during the first trimester of pregnancy. These warnings were introduced after the thalidomide disaster in the early 1960s. However, limiting the exercise of caution to the first month of pregnancy is both short sighted and effectively impossible -first, because chemicals can affect any stage of pre -or post natal development; and secondly, because when a woman first learns that she is pregnant, the process of organogenesis has already long since begun (for example, the neural tube has closed). Hence, unborn could already be inadvertently exposed to maternal drug treatment during the early embryonic period.

\section{HUMAN FERTILIZATION}

The definition of human fertilization is the union or joining of the egg and the sperm, resulting in a fertilized egg, otherwise known as a zygote. Human fertilization begins with a woman's menstrual cycle. This cycle prepares a woman's body for fertilization. About half way through this cycle, the woman's body is ready to begin the process of human fertilization. It is at this point that an egg cell is released, or ovulated, into the fallopian tube. Inside this Fallopian tube, fertilization will take place. 


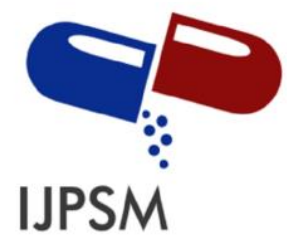

Sakshi Ahirwar et al, Int. Journal of Pharmaceutical Sciences and Medicine (IJPSM), Vol.6 Issue. 8, August- 2021, pg. 78-103

ISSN: 2519-9889

Impact Factor: 3.426

During intercourse, a man can ejaculate, or release semen into a women's vagina. There are up to 150 million sperm in the semen in the single ejaculation. The sperm travel to the fallopian tube to meet the egg; however, the sperm have some big challenges ahead to complete this journey .For instance, the sperm have to complete this journey within 12-48 hours of the egg being ovulated, or else they will die. This process, from ejaculation to the remaining sperm reaching the egg, takes about 20 minutes. At this point there are only a few dozen sperm left that actually make it to the egg. The remaining sperm being to surround the egg, and they race to be the first and only sperm to actually fertilize the egg.

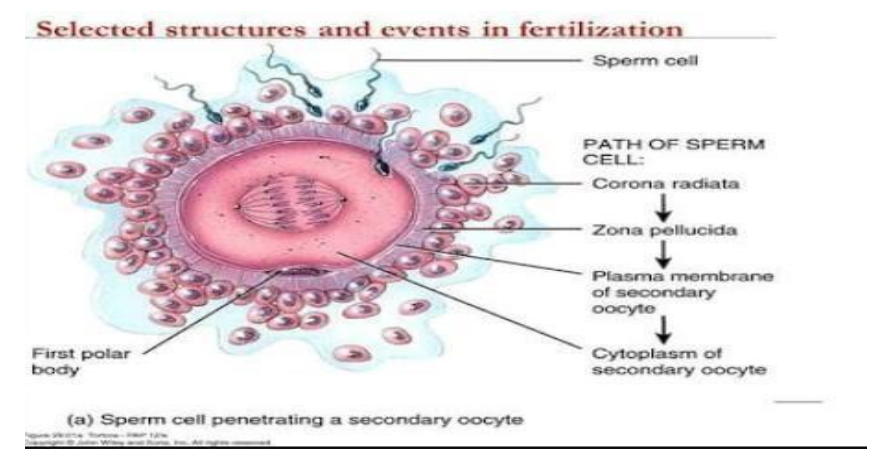

Figure: 1 Events in Fertilization

\section{PRENATAL DEVELOPMENT}

Prenatal development (from latin natalis, meaning 'relating to birth') is the process in which an embryo and later fetus develops during gestation .Prenatal developments starts with fertilization, the first stage in embryogenesis which continues in fetal development until birth. In the human pregnancy, prenatal development, also known as antenatal development is the development of the embryo .By the end of the fourth week of gestational age, the embryo has acquired its basic form and is referred to as a fetus. The next period is that of fetal development where many organs become fully developed. This fetal period is describe both topically (by organ) and chromologically (by time) with major occurences being listed by gestational age. In the other animals the very early stages of embryogenesis are the same as those in humans. In later stages, development across all taxa of animals and the length of gestation vary.

\section{CONFIRMATION PREGNANCY TEST HOME PREGNANCY TESTS}

A home pregnancy test (HPT) can be used on the first day of your missed period. Some very sensitive tests can be used even earlier. These tests work by detecting the hormone human 


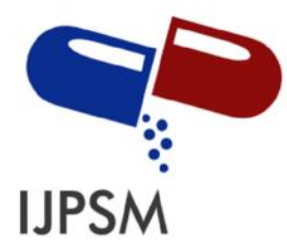

Sakshi Ahirwar et al, Int. Journal of Pharmaceutical Sciences and Medicine (IJPSM), Vol.6 Issue. 8, August- 2021, pg. 78-103

ISSN: 2519-9889

Impact Factor: 3.426

chorionic gonadotropin (hCG) in your urine. This hormone is only found in the body during pregnancy. A chemical in the stick changes color when it comes into contact with this hormone. Waiting times will vary depending in the test, but most take about 10 minutes to deliver an accurate reading.

\section{HCG Urine Test}

A human chorionic gonadotropin urine test is a pregnancy test. A pregnant woman's placenta produces hCG, also called the pregnancy hormone. If you're pregnant, the test can usually detect this hormone in your urine about 10 days after your first missed period. This is when the fertilized egg attaches to the uterine wall. During the first 8 to 10 weeks of pregnancy, hCG levels normally increase very rapidly. These levels reach their peak at about the 10th week of pregnancy, and then they gradually decline until delivery.

\section{Blood Tests}

There are two types of blood tests. A quantitative blood test measures the exact amount of hCG in the blood, and a qualitative hCG blood test gives a simple yes or no answer to whether you are pregnant or not. Can detect a pregnancy earlier than a urine test at about 7-12 days from possible conception (but if a negative result is received, a test should be repeated if a period is missed). Can measure the concentration of hCG hormone in your blood (this is useful information to your healthcare provider in tracking certain problems in pregnancy).

\section{TEST DURING PREGNANCY}

First trimester prenatal screening tests

First trimester screening is a combination of fetal ultrasound and maternal blood testing. This screening process can help determine the risk of the fetus having certain birth defects. Screening tests may be used alone or with other tests.

\section{Ultrasound for fetal nuchal translucency}

Nuchal translucency screenings uses an ultrasound to examine the area at the back of the fetal neck for increased fluid or thickening.

\section{Ultrasound for fetal nasal bone determination}

The nasal bone may not be visualized in some babies with certain chromosome abnormalities, such as down syndrome. This screen is performed using an ultrasound between 11 and 13 weeks gestation.

\section{Second Trimester Prenatal Screening Tests}

Second trimester prenatal screening may include several blood tests called multiple markers. Screening is usually done by taking a sample of your blood between 15 and 20 weeks of 


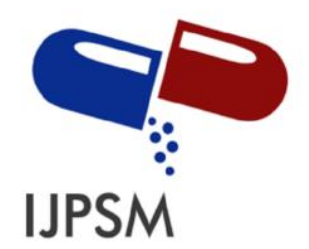

Sakshi Ahirwar et al, Int. Journal of Pharmaceutical Sciences and Medicine (IJPSM), Vol.6 Issue. 8, August- 2021, pg. 78-103

ISSN: 2519-9889

Impact Factor: 3.426

pregnancy (16 to 18 weeks is ideal). The multiple markers include.

\begin{abstract}
AFP Screening
Also called maternal serum AFP, This blood test measures the level of AFP in your blood during pregnancy. AFP is a protein normally produced by the fetal liver that is present in the fluid surrounding the fetus (amniotic fluid). It crosses the placenta and enters your blood. Abnormal levels of AFP may indicate
\end{abstract}

\title{
AMNIOCENTESIS
}

An amniocentesis involves taking a small sample of the amniotic fluid that surrounds the fetus. It is used to diagnose chromosomal disorders and open neural tube defects, such as spina bifida. Testing is available for other genetic defects and disorders depending on your family history and the availability of lab testing at the time of the procedure.

\section{FIRST TRIMESTER OF PREGNANCY (1, 2, 3 month segments)}

Pregnancy is considered to being at the first day of the mother's last menstrual period. Conception typically occurs at what is considered the $2^{\text {nd }}$ week of pregnancy.

Conception is also the beginning of the germinal period of prenatal development. This stage occurs during the first 2 weeks of development (or the $2^{\text {nd }}$ and $4^{\text {th }}$ weeks of pregnancy).

The union of the sperm and egg cell forms a single cell called a zygote. The zygote moves along the fallopian tube towards the uterus .At the same time, the zygote is rapidly dividing in a process called cleavage.

Once it reaches the uterus, the zygote becomes what is called a blastocyst, and it begins to implant into the wall of the uterus. The germinal period ends when the blastocyst is fully implanted into uterine tissue

\section{THE ZYGOTE (First trimester first 2 weeks)}

Fertilized egg reaches the uterus and attaches itself to the uterus. The cell multiplication begin. The first trimester begins on the first day of your last period and lasts until the end of week 12. The fertilized egg rapidly divides into layers of cell and implants in the wall of your womb where it carries on growing. These layers of cells become an embryo, which is what the baby is called at this stage. 


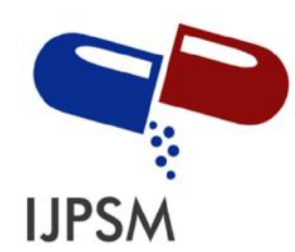

Sakshi Ahirwar et al, Int. Journal of Pharmaceutical Sciences and Medicine (IJPSM), Vol.6 Issue. 8, August- 2021, pg. 78-103

ISSN: 2519-9889 Impact Factor: 3.426

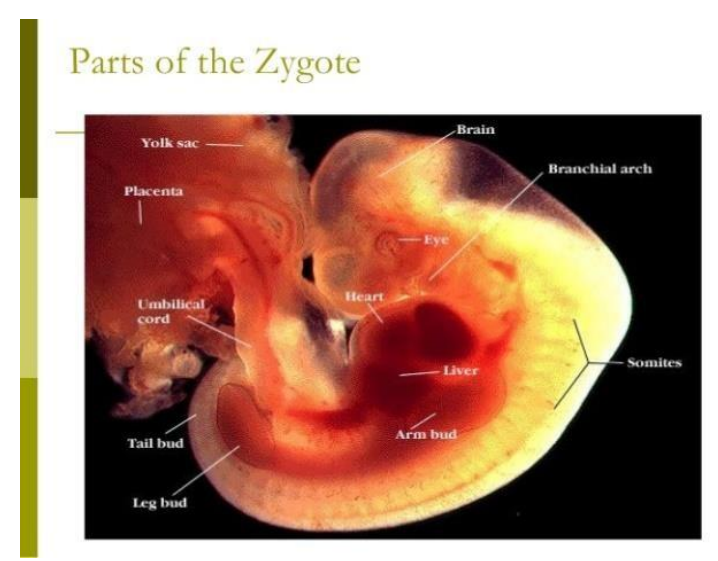

Figure: 2 Parts of zygote

During this trimester, your baby grows faster than at any other time. By six weeks, a heartbeat can usually be heard and by the end of week 12, your baby's bones, muscles and all the organs of the body have formed. At this point, yours looks like a tiny human being and is now called a fetus. He or she will even be practicing swallowing.

\section{FIRST MONTH (week 1-4)}

First month of pregnancy as the first month since your last period, so for about the first two weeks. As soon as fertilization takes place, the egg begins to grow and split into multiple cells. This early collection of cells is called a zygote. Over the course of several days, the zygote makes its way down the fallopian tube to the uterus. Just as it does each month, the lining of the uterus has become soft, spongy and full of nutrients, making it the ideal place for the zygote to implant. Once the zygote implants itself into the wall of your uterus your body knows you are pregnant.

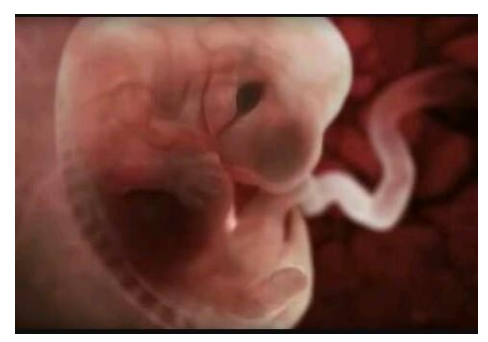

Figure: 3 First month baby

THE SECOND MONTH (weeks 5-8)

In the second month of pregnancy your little blastocyst is starting to take form and is now called EMBRYO. This is the most important time of prenatal development because the 


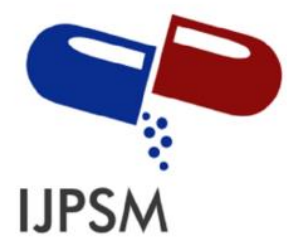

Sakshi Ahirwar et al, Int. Journal of Pharmaceutical Sciences and Medicine (IJPSM), Vol.6 Issue. 8, August- 2021, pg. 78-103

ISSN: 2519-9889

Impact Factor: 3.426

embryo is developing the foundations for a healthy baby. The blastocyst that implanted in the uterus continues to divide rapidly after implantation. Through a process called differentiation, cells begin to take 4 on different functions. One of the first examples of this is a division between the cells that will make up the placenta and the cells that will make up the baby. After this a process called gastrulation forms three layers called germ layers. The outer layer is called the ectoderm, the middle layer is called as mesoderm, and the inner layer called the 4 endoderm. Each germ layer will differentiate into different structured. The ectoderm will form many outer tissues such as skin and hair, as well as not of the nervous system tissues including the brain. The mesoderm will form tissues inside the body such as the lungs, bones, and muscles-including the heart. The endoderm will form tissues such as the digestive tract and bladder, as well as other internal organs.

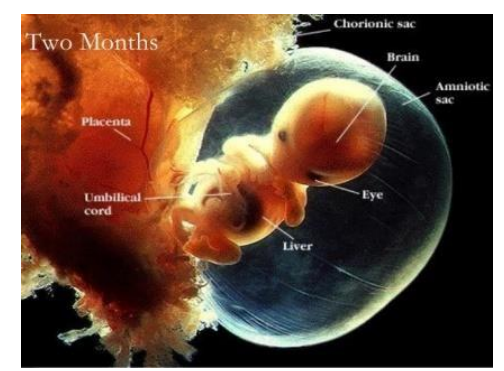

Figure: 4 Two months baby (embryo)

EMBRYOGENESIS is a term that can be used to describe all of the process of embryo development up until the time it becomes a fetus.

\section{THE THIRD MONTH (weeks 9-12)}

In the third month of pregnancy, your baby (now called as fetus), will grow a lot .By the end of the third month of pregnancy, your baby is about and 3.5 inches long -about the size of a plum. Although your baby is still very small, all his or her body parts and systems are in place. And actually, he or she is now officially a he or she - as the sex organs are developing, though they can't be seen on an ultra sound quite yet. Your baby has grown fingers and toes, as well as fingers nails and toes nails. Bones, cartilage and teeth under the gums are forming and so are your baby's muscles. Your baby can move his or her arms and legs (though you won't feel it for a couple more months). Your baby face has also formed and he or she may start sucking on a thumb or fist. Baby is making digestive juices and excreting urine. 


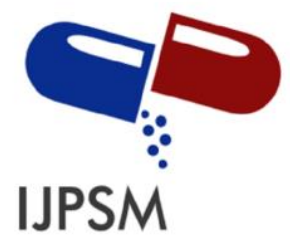

Sakshi Ahirwar et al, Int. Journal of Pharmaceutical Sciences and Medicine (IJPSM), Vol.6 Issue. 8, August- 2021, pg. 78-103

ISSN: 2519-9889

Impact Factor: 3.426

\section{Months}

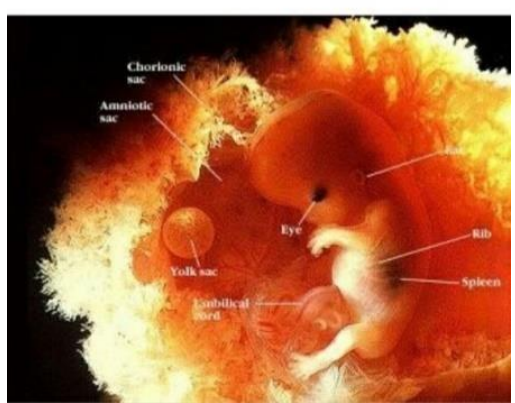

Figure: 5 Third months

\section{SECOND TRIMESTER OF PREGNANCY $(4,5,6$ month segments)}

The second trimester of your pregnancy is from week 13 to week 28 -roughly months four, five and six. As well as feeling and looking more pregnant during these weeks, you may also have more energy than you did in the first trimester. This will come as a great relief if you have been struggling with sickness, tiredness or anxiety about getting through the first trimester.

\section{FOUR MONTH (week 13 -16)}

By the end of this month, your baby is about six inches long -the size of a large orange. His or her bones are starting to harden, though his skin is still thin and translucent. His or her body is covered with the fine downy hair called lanugo that will stay with him or her most of the pregnancy. He or she is also growing hair on his or her head as well as eyes brows and eyelashes. His or her outer ears are developing. Inside his or her ears, tiny bones are starting to harden and he may be able to hear some sounds. At this time, baby spends a lot of time sucking and swallowing -skills he or she will need when he or she leaves your womb.

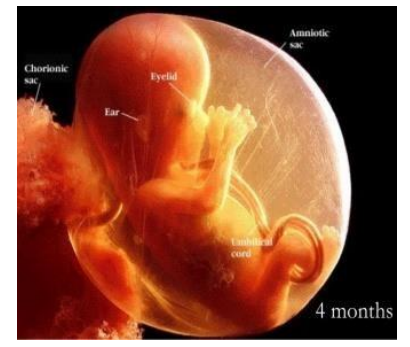

Figure: 6 Fourth month baby 


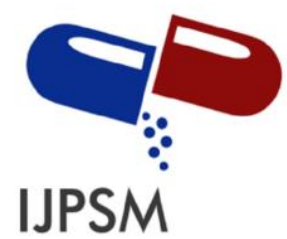

Sakshi Ahirwar et al, Int. Journal of Pharmaceutical Sciences and Medicine (IJPSM), Vol.6 Issue. 8, August- 2021, pg. 78-103

ISSN: 2519-9889

Impact Factor: 3.426

\section{FIFTH MONTH ( weeks 17-20)}

In the fifth month of pregnancy your baby will be 8-12 inches long and could weigh up to a pound. Your baby is developing the thick white subtance called vernix that will cover his body until birth to protect his or her thin skin from the amionatic fluid. Your baby's bones ans muscles are developed now ans she can strech, yawn and facial expressions. He and she is also sleeping and waking, probably on a fairly regular schedule. Your baby is also devloping his or her unique fingerprints. If your baby is boy, his testicles are descending. If ypur baby is girl, her uterus is fully formed and she has eggs in her ovaries. Now your uterus size of a cantaloupe, and

you are probably wearing maternity clothes. The ligaments in your abdomen are streching and you may be seeing strech marks . In addition to aches in youe abdomen, you may be getting legs cramps, mild swelling in your feet and ankles and backaches.

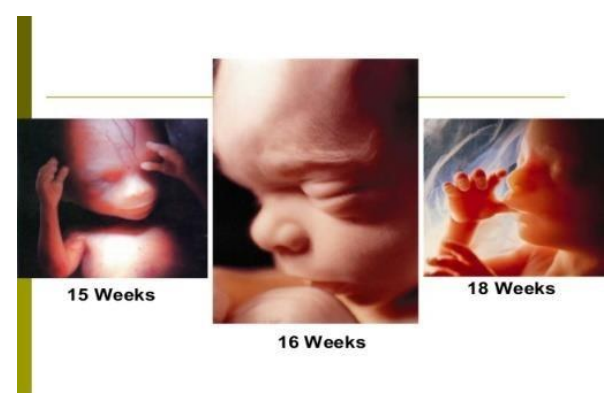

Figure: 7 Fifth month baby

\section{SIXTH MONTH OF PREGNANT (week 21-24)}

At twenty weeks, the developing baby is about 6 inches long $(13.2 \mathrm{~cm})$ and may weigh about 10 ounces. The baby may begin to make movements that the mother can feel at about 19 to 21 weeks; this baby movement is termed "quickening". The baby at this stage of development can move its facial muscles, yawn, and suck its thumb. The expanding uterus at 20 weeks is felt at the level of the belly button.

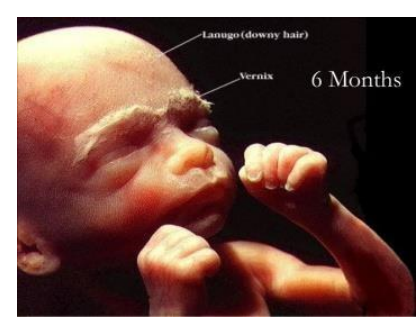

Figure: 8 sixth month baby 


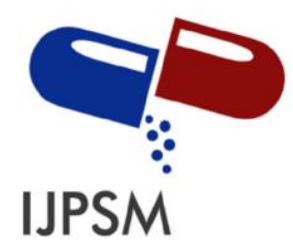

Sakshi Ahirwar et al, Int. Journal of Pharmaceutical Sciences and Medicine (IJPSM), Vol.6 Issue. 8, August- 2021, pg. 78-103

ISSN: 2519-9889

Impact Factor: 3.426

By the end of this month your baby is nearly fully formed. However, his or her organs are still developing and his or her lings are not yet developed enough to breathe on his or her own. Your baby's head is nearly proportional to his or her body and his or her face is fully developed right down to the eyelids and eyebrows. Although your baby's eyes are still fused shut, he or she can sense light and dark. Your baby's skin is no longer translucent and he or she starting to gain fat to help keep him or her warm. His or her muscles are getting stronger, which you might be noticing as he kicks and squirms.

$\mathrm{He}$ or she is also producing the white blood cells will help him or her to fight diseases. Your baby is now just over a foot long and weighs one to one a half pounds.

\section{THIRD TRIMESTER OF PREGNANCY (7,8,9 month segments)}

The third trimester begins in week 28 of pregnancy and lasts until you give birth, which may be around week 40 of pregnancy. In the other words, your third trimester lasts from month 7 through month 9 of pregnancy.

\section{SEVEN MONTH OF PREGNANCY (week 25-28)}

Now in seven month of pregnancy your baby's brain and nervous system are growing fast now and his or her lungs are beginning to function. Your baby's hearing is now fully developed. Sleeping and waking cycles are more pronounced and your baby is dreaming when she or he is sleeping. Your baby can cry and open her eyes. He or she is getting too big to move around too much, though she will certainly continue to kick and may turn somersaults. The soft downy lanugo is starting to disappear.

By the end of this month your baby will be about a foot and a half long and weigh about three pounds. Babies born at 28 weeks, though premature, have a good chance of surviving with proper care.

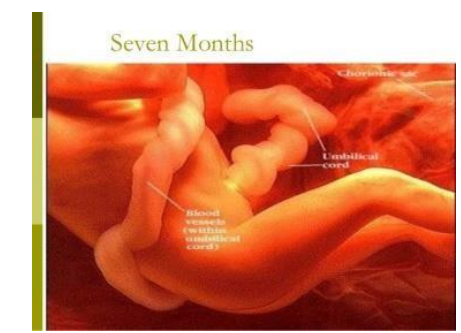

Figure: 9 Seven month baby

\section{EIGHTH MONTH PREGNANCY (week 29-32)}

Your baby's body is pretty much completely formed now, though the lungs and brain still developing. Your baby can now blink at will and his or her pupils dilate in response to light and dark. Your baby continue to grow and gain fat. He or she is gaining about a pound a week. 


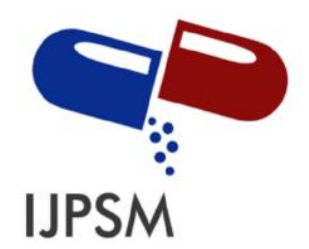

Sakshi Ahirwar et al, Int. Journal of Pharmaceutical Sciences and Medicine (IJPSM), Vol.6 Issue. 8, August- 2021, pg. 78-103

ISSN: 2519-9889

Impact Factor: 3.426

By the end of this month he or she will up to 19 inches long and weigh about five or six pounds. Space is getting cramped and he or she probably not moving around as much as he or she is used to. By now, he has probably settled into head- down position that he or she stay in until birth.

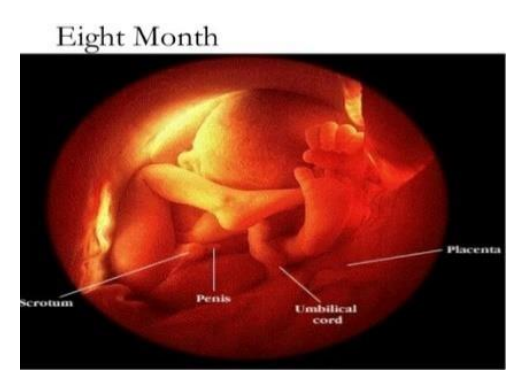

Figure: 10 Eighth month baby

\section{NINTH MONTH OF PREGNANCY (weeks 38-40)}

While pregnancy is said to be nine months long, a full term baby is actually $38-40$ weeks old closer to ten months. Your baby is now fully formed and is getting ready for life outside the womb. She or he's gaining weight and her or his brain is continuing to grow and develop. With the exception of her skull -which stays soft so that she can make it through the birth canal- her or his bones have hardened.

Her reflexes are coordinated and she or he can blink, graps, and turn her or his head. There's less vernix on her or his body now and the downy lanugo has probably completely disappeared.

Your baby may have "dropped"- which means she or he's sitting lower in your pelvis. Your baby is nearly ready to be born. As you approach the end of the third trimester, your baby is probably around 20 inches long and weighs between six and seven and eight pounds.

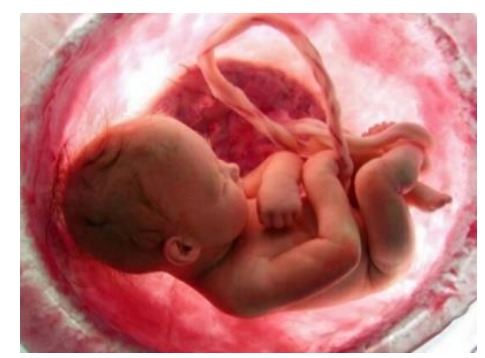

Figure: 11 Ninth month baby 


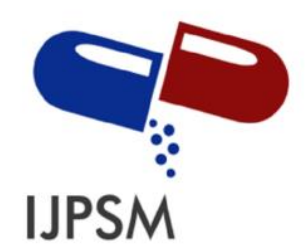

Sakshi Ahirwar et al, Int. Journal of Pharmaceutical Sciences and Medicine (IJPSM), Vol.6 Issue. 8, August- 2021, pg. 78-103

ISSN: 2519-9889

Impact Factor: 3.426

\section{Types of Miscarriage}

- Threatened miscarriage:

When your body is showing signs that you might miscarry, that is called a 'threatened miscarriage'. You may have a little vaginal bleeding or lower abdominal pain. It can last days or weeks and the cervix is still closed.

The pain and bleeding may go away and you can continue to have a healthy pregnancy and baby. Or things may get worse and you go on to have a miscarriage.

\section{- Inevitable miscarriage}

Inevitable miscarriage can come after a threatened miscarriage or without warning. There is usually a lot more vaginal bleeding and strong lower stomach cramps. During the miscarriage your cervix opens and the developing fetus will come away in the bleeding.

\section{- Complete miscarriage}

A complete miscarriage has taken place when all the pregnancy tissue has left your uterus. Vaginal bleeding may continue for several days. Cramping pain much like labor or strong period pain is common this is the uterus contracting to empty.

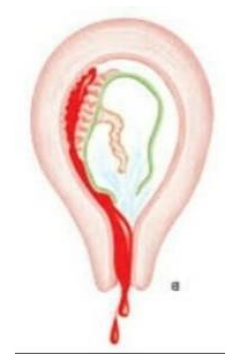

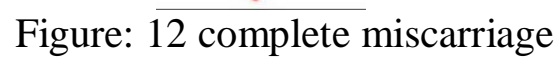

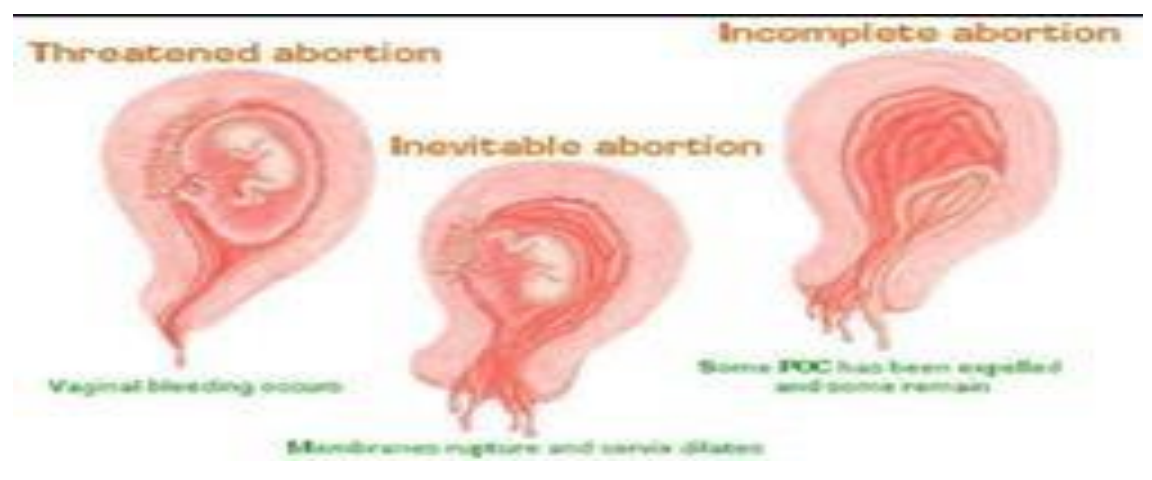

Figure 13: types of miscarriage 


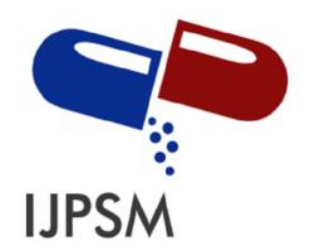

Sakshi Ahirwar et al, Int. Journal of Pharmaceutical Sciences and Medicine (IJPSM), Vol.6 Issue. 8, August- 2021, pg. 78-103

ISSN: 2519-9889

Impact Factor: 3.426

\section{- Incomplete miscarriage}

Sometimes, some pregnancy tissue will remain in the uterus. Vaginal bleeding and lower abdominal cramping may continue as the uterus continues trying to empty itself. This is known as an incomplete miscarriage.

\section{- Missed miscarriage}

Sometimes, the baby has died but stayed in the uterus. This is known as a missed miscarriage. If you have a missed miscarriage you may have a brownish discharge. Some of the symptoms of pregnancy, such as nausea and tiredness, may have faded. You might have noticed nothing unusual. You may be shocked to have a scan and find the baby has died.

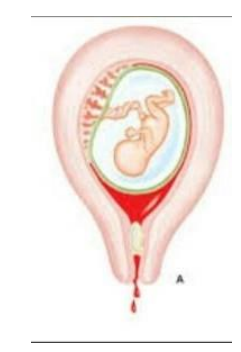

Figure: 14 missed miscarriage

\section{- Recurrent miscarriage}

A small number of women have repeated miscarriages. If this is your third or more miscarriage in a row.

\section{DRUG THERAPY IN PREGNANCY}

More than $50 \%$ of pregnant women take prescription or nonprescription (over -thecounter) drugs or use social drugs (such as tobacco and alcohol). In general, drugs should not be used during pregnancy unless absolutely necessary because many can harm the fetus.

\section{Physiological changes during pregnancy}

- BMR increases by $15-20 \%$, weight gain $-11 \mathrm{~kg}$, postural changes

- GIT changes decreased gastric motility \& emptying, nausea \& vomiting.

- CVS changes CO increases by $40 \%$, plasma volume by $45 \%$, low DBP

- Decreased serum albumin levels

- Hyper coagulability of blood

- Increased GFR \& renal blood flow 


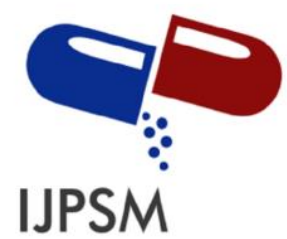

Sakshi Ahirwar et al, Int. Journal of Pharmaceutical Sciences and Medicine (IJPSM), Vol.6 Issue. 8, August- 2021, pg. 78-103

ISSN: 2519-9889 Impact Factor: 3.426

\begin{tabular}{|l|l|l|}
\hline $\begin{array}{l}\text { PHARMACOKINETIC } \\
\text { PARAMETER }\end{array}$ & $\begin{array}{l}\text { PHYSIOLOGICAL } \\
\text { PARAMETER }\end{array}$ & EFFECT \\
\hline Absorption & $\begin{array}{l}\text { Increase gastric emptying } \\
\text { time Increase gastric acid Ph } \\
\text { Decrease GI motility }\end{array}$ & $\begin{array}{l}\text { Increase or decrease } \\
\text { systemic absorption of } \\
\text { medications }\end{array}$ \\
\hline Distribution & $\begin{array}{l}\text { Increase plasma volume } \\
\text { Increase adipos tissue } \\
\text { volume Increase cardiac } \\
\text { output }\end{array}$ & $\begin{array}{l}\text { Increase volume of } \\
\text { distribution } \\
\text { Decrease plasma drug } \\
\text { concentration }\end{array}$ \\
\hline Excretion & $\begin{array}{l}\text { Increase GFR and renal blood } \\
\text { flow }\end{array}$ & $\begin{array}{l}\text { Increase clearance of } \\
\text { drugs that are cleared } \\
\text { through the kidney }\end{array}$ \\
\hline Protein binding & Decrease albumin concentration & $\begin{array}{l}\text { Increase free drug } \\
\text { concentration of highly } \\
\text { protein bound drugs }\end{array}$ \\
\hline
\end{tabular}

Table no. 1 Physiology changes during pregnancy

Placental Transfer of Drugs

- Rate of transfer of drug across depends on:

- Lipid solubility

- Ionization of drug

- Molecular size

- PPB

- PH difference -[7.0 vs 7.4]- ionic trapping of weak basic drugs-morphine

Further, placenta is capable of metabolizing drugs. Is of little relevance to the mother. But has protective effect on fetus.Eg: prednisolone \& hydrocortisone are metabolized to inactive compounds (prednisone, cortisone) safer for fetus. 


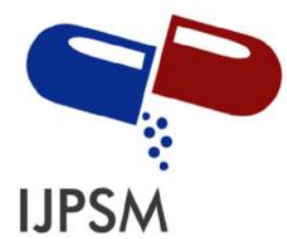

Sakshi Ahirwar et al, Int. Journal of Pharmaceutical Sciences and Medicine (IJPSM),

Vol.6 Issue. 8, August- 2021, pg. 78-103

ISSN: 2519-9889

Impact Factor: 3.426

\section{GESTATION MAY BE DIVIDED INTO 4 STAGES:}

Stages of blastocyst formation

- 0-16 days

- A teratogen may either kill embryo by inhibiting cell division

- If embryo survive exposure to drug subsequent development normal

- All or None phenomenon

Stage of organogenesis

- 17-60 days

- A teratogen given during this stage gross structural malformation

Final stage of histogenesis \& maturation:

Fetus receives adequate supply of nutrients-growth \&development

Teratogens - deleterious effect on growth \& development

Eg. DES -dysplasia, vaginal cancer in the female offspring. Exposure to androgens masculinization of female fetus

\section{Short labor delivery stage}

Drug administered during this phase risk of neonatal toxicity 'terato' ; 'genesis'.

Originally used- describe congenital malformation grossly visible at birth \& caused by a teratogen.

Now definition includes 'structural, biochemical and behavioral abnormalities' It should result in characteristic set of malformation. Exert its effect in particular stage of fetal development. Show dose dependent incidence.

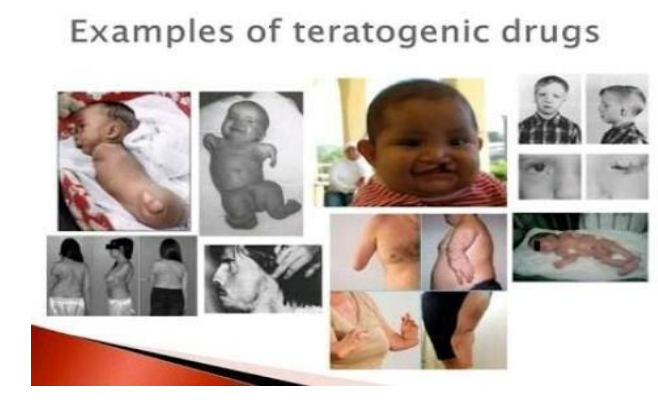

Figure: 15 Example of teratogenic drugs 


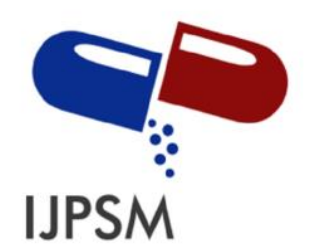

Sakshi Ahirwar et al, Int. Journal of Pharmaceutical Sciences and Medicine (IJPSM), Vol.6 Issue. 8, August- 2021, pg. 78-103

ISSN: 2519-9889

Impact Factor: 3.426

\section{History of Thalidomide}

- Originally developed in Germany in 1954

- Introduced as hypnotic \& sedative in 1957

- Even recommended in pregnancy as a safe hypnotic

- Teratogenic testing only in mice embryo cells was done

- In 1961- $1^{\text {st }}$ phocomelia case was reported

- Drug was withdrawn in 1961

\section{FDA CATEGORIES FOR DRUG USE IN PREGNANCY}

1979, FDA developed a system determining teratogenic risk of drugs based on animals\& human studies. Divided drugs into 5 categories

- Category A

- Category B

- Category C

- Category D

- Category X

\section{Category A}

Drugs in this category have controlled studies in pregnant women that have failed to demonstrate harm to the fetus in the first trimester\& have no evidence of further risk in later trimesters.

Folic acid \& vitamin B12

\section{Category B}

Animal studies have failed to demonstrate a risk to the fetus and but there are no adequate and well controlled studies in pregnant women.

Acetaminophen, insulin \& famotidine

\section{Category C}

Animal reproduction studies have shown an adverse effect on the fetus and there are no adequate \& well controlled studies in humans

But potential benefits may warrant use of the drug in pregnant women despite potential risks.

Pseudoephedrine, fluconazole, ciprofloxacin, fexofenadine, escitalopram, fluoxetine \& bupropion 


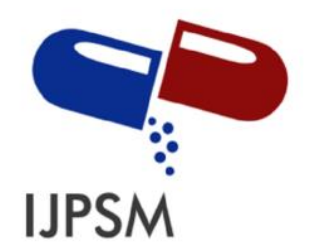

Sakshi Ahirwar et al, Int. Journal of Pharmaceutical Sciences and Medicine (IJPSM), Vol.6 Issue. 8, August- 2021, pg. 78-103

ISSN: 2519-9889

Impact Factor: 3.426

\section{Category D}

There are positive evidence of human fetal risk based on the adverse reaction data from controlled studies in pregnant humans. But potential benefits may warrant use of the drugs in pregnant women despite potential risks.

Phenytoin

\section{Category X}

Adequate well controlled or observational studies have been done in pregnant women or in animals and have demonstrated positive evidence of fetal abnormalities.

The use of the product is contraindicated in women who are or may become pregnant

Warfarin, medroxyprogesterone, estrogen and methotrexate

\section{DRUGS WITH PROVEN TERATOGENIC EFFECTS}

Phenytoin

- Fetal hydantoin syndrome

- Cleft lip, cleft palate\& congenital heart disease

Vitamin A derivatives:

- Isotretinoin, etretinate

- Significant risk of spontaneous abortion \& risk of many significant anomalies

ACEIs

- Renal damage used $2^{\text {nd }} \& 3^{\text {rd }}$ trimester

- Oligohydraminos

- Anomalies of face, limbs \& lungs

Valproate \& Carbamazepine

- Spina bifida

- Anencephaly

- Encephalocele

Warfarin

- Fetal warfarin syndrome

- Nasal hypoplasia, depressed nasal bridge \& hemorrhagic disorders in fetus

NSAIDs

- Premature closure of ducts arteriosus 


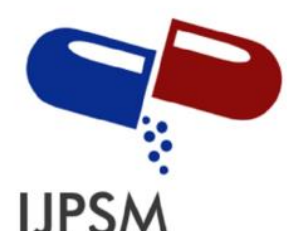

Sakshi Ahirwar et al, Int. Journal of Pharmaceutical Sciences and Medicine (IJPSM),

Vol.6 Issue. 8, August- 2021, pg. 78-103

ISSN: 2519-9889

Impact Factor: 3.426

\section{DRUGS AND TERATOGENIC EFFECTS}

\begin{tabular}{|l|l|}
\hline DRUGS & TERATOGENIC EFFECTS \\
\hline Trimethadione & $\begin{array}{l}\text { simian creases in the hands, cardiac anomalies, } \\
\text { irregular teeth and mental retardation }\end{array}$ \\
\hline Lithium & Ebstein's anomaly (tricuspid valve malformation) \\
\hline $\begin{array}{l}\text { Aspirin and there } \\
\text { salicylates }\end{array}$ & $\begin{array}{l}\text { Premature closing of ducts arteriosus \& bleeding } \\
\text { problems }\end{array}$ \\
\hline Cyclophosphamide & CNS malformation, secondary cancer \\
\hline Methotrexate & NTD \\
\hline Tetracycline & Anomalies of teeth \& bone \\
\hline Chloramphenicol & Gray baby syndrome \\
\hline
\end{tabular}

Table no. 2 teratogenic effect

Precautions while prescribing for women of reproductive age

Enquire whether she is pregnant/ likely to be in near future. Advised to avoid conception for certain period of time with certain drugs

- Isotretinoin-1 month

- Mefloquine - 3 month

- Cytotoxic drugs - 1 year

Must be informed to use contraceptive measures when a teratogenic drug is prescribed

\section{Precautions while prescribing during pregnancy}

- Treat minor ailments without drugs.

- Doctor must know the safety potential of the drug he prescribe.

- Always prefer drug which has been in market over a longer time than a new drug.

- Make dose adjustment. 


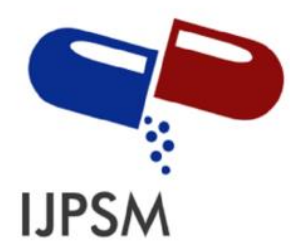

Sakshi Ahirwar et al, Int. Journal of Pharmaceutical Sciences and Medicine (IJPSM),

Vol.6 Issue. 8, August- 2021, pg. 78-103

ISSN: 2519-9889

Impact Factor: 3.426

- Discourage patient from OTC drug use.

- Centered on benefit verses risk potential ( epilepsy)

\section{COMMONLY DRUG USED IN PREGNANCY}

\section{ANALGESICS \& ANTIPYRETIC}

- Acetaminophen, phenacetin, aspirin

- Use of NSAIDs avoided towards end of the pregnancy - premature closure of ductus arteriosus

\section{ANTIEMETICS}

- Antihistaminics - cyclizine, meclizine

- Ondansterone

ANTIBIOTICS

- Beta lactum antibiotics safe

- Nitrofurantoin is safe

- Erythromycin is safe; estolate salts are avoided

ANTIAMOEBIC DRUGS

- Metronidazole can be used

ANTIMALARIALS

- Chloroquine can be used Rx of acute attacks

- Quinine - chloroquine resistant malaria

ANTI TB DRUGS

- Isoniazide \& ethambutol are safe

- Rifampicin avoided as far as possible due to hepato- toxicity may be used as a $3^{\text {rd }}$ drug

- Streptomycin is CI - ototoxicity

ANTIFUNGAL DRUGS

- Nystatin \& miconazole - safe in pregnancy

- Ketoconazole - CI 


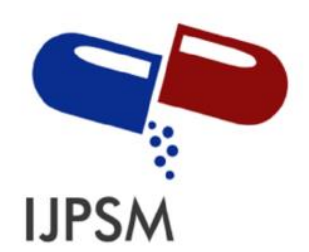

Sakshi Ahirwar et al, Int. Journal of Pharmaceutical Sciences and Medicine (IJPSM),

Vol.6 Issue. 8, August- 2021, pg. 78-103

ISSN: 2519-9889

Impact Factor: 3.426

\section{ANTIASTHMA DRUGS}

- Beta agonists ( inhaled), gluococorticoids (inhaled)

\section{CARDIAC DRUGS}

- Digoxin \& quinidine

\section{ANTIHYPERTENSIVES}

- Methyldopa is DOC

- Labetalol IV for sudden decrease in BP

\section{ANTICOAGULANT}

- Heparin

\section{ANTIHELMINTHES}

- Piperazine, pyrantel

\section{ANTIEPILEPTICS}

- Adequate seizure control necessary for both fetus \& mother health.

- Phenytoin, phenobarbiturate, carbamazepine

- Valproate - CI in pregnancy

- Here benefits outweights risk

- Folic acid supplementation given

COUGH- Codeine, diphenhydramine, dextromethorphan

HEART BURN- Non systemic antacids

CONSTIPATION- Milk of magnesia, glycerin, bisacodyl

\section{VACCINES}

\section{THYROTOXICOSIS-}

Propylthiouracil

\section{HYPOTHYROIDISM-}

Thyroxine Concern with OTC drugs

- In India due to easy availability of drugs $\&$ poor health services

- Hence consumers always face a threat to unwanted ADRs \& drug- drug interaction 


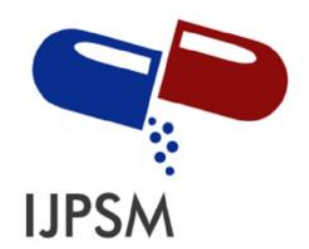

Sakshi Ahirwar et al, Int. Journal of Pharmaceutical Sciences and Medicine (IJPSM), Vol.6 Issue. 8, August- 2021, pg. 78-103

ISSN: 2519-9889

Impact Factor: 3.426

- Many OTC drugs are unsafe during pregnancy

- Women who are/ maybe / planning to be pregnant must consult a doctor before taking any OTC drug.

\section{COMMON HERBS USED IN PREGNANCY}

\section{Red raspberry leaf}

Rich in iron this herb has helped tone the uterus increase milk production decrease nausea, and ease labor pains. And also reduce the complications during birth. Promote the uterine health during pregnancy.

\section{Peppermint leaf}

Helpful in relieving nausea / morning sickness and flatulence.

\section{Ginger root}

Helps relieve nausea and vomiting

Slippery elm bark

(When the inner bark is used orally in amounts used in foods) used to help relieve nausea, heartburn, and vaginal irritations

\section{Oats \& Oat straw}

Rich in calcium and magnesium helps relieve anxiety, restlessness, and irritated skin.

\section{Dandelion-}

Rich in vitamin A, calcium, and iron dandelion root and leaf can also help relieve mild edema and nourish the liver.

\section{Chamomile (German)-}

High $\mathrm{n}$ calcium and magnesium also helps with sleeplessness and inflammation of joints.

\section{Nettles (Stinging Nettles)-}

High in vitamin A, C, K calcium, potassium, iron. Used in many pregnancy teas because it is a great all around pregnancy tonics.

\section{HERBS THAT ARE AVOIDED DURING PREGNANCY}

\section{Saw Palmetto}

The oral intake of this medicinal herb can trigger hormonal activity. 


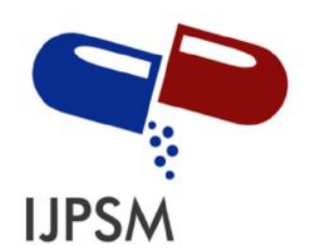

Sakshi Ahirwar et al, Int. Journal of Pharmaceutical Sciences and Medicine (IJPSM),

Vol.6 Issue. 8, August- 2021, pg. 78-103

ISSN: 2519-9889

Impact Factor: 3.426

\section{Goldenseal}

If you are pregnant you should avoid consuming goldenseal. It can cross the placenta and adversely affect the development of the brain in the fetus.

\section{Dong Quai}

Pregnant women should stay away from dong quai as it can cause uterine contractions and lead to a miscarriage.

\section{Ephedra}

The oral use of the herb can cause uterine contractions and premature labor. So do avoid herbal products that contain ephedra when you are pregnant.

\section{Pau D'arco}

Large doses of the herb can spell danger during pregnancy.

\section{MEDICATIONS AND LACTATION}

Medications that increase lactation

- Metoclopramide

- Domperidone

- Phenothiazine neuroleptics-chlorpromazine

- Risperine

- Hypoglycemics

- $\mathrm{H} 2$ antagonist - cimetidine

- Antihypertensive methyldopa, b blockers

\section{Medications that reduce lactation}

- Bromocryptine (dopamine agonist)

- Progesterone, estrogen-OCP

- Clomiphene citrate

- Ergotamine

- Pseudoephedrine( in cough syrups)

- Pyridoxine

- Prostaglandins- PGE/F2 alpha

- Levodopa/carbidopa 


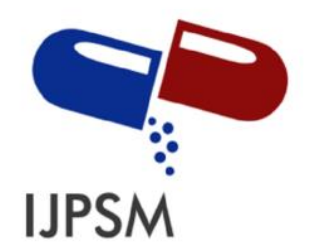

Sakshi Ahirwar et al, Int. Journal of Pharmaceutical Sciences and Medicine (IJPSM), Vol.6 Issue. 8, August- 2021, pg. 78-103

ISSN: 2519-9889

Impact Factor: 3.426

\section{Advice to the mother to improve lactation}

- Good health

- Early and sufficient treatment of illness

- Proper balance between rest and excerise

- Freedom from worry

- Plenty of fluids

- Adequate nutrition

- Care of the breast and nipple during pregnancy

\section{CONCLUSIONS:}

Pregnancy and birth can be very special time in the life of a woman. The nine months of pregnancy, as well as labor and delivery, are filled with many physical and psychological changes, as well as changes in lifestyle. Pregnancy is typically broken into three trimesters, each of about three months. In each trimester the development of fetus takes place. According to trimester the drugs belong to FDA categorization and their teratogenic effect on the mother and her fetus are given to the mother.

\section{ULTRA SOUND DURING FIRST, SECOND AND THIRD TRIMESTER OF PREGNANCY}

The first fetal ultrasound is usually done during the first trimester to confirm and date of the pregnancy. If your pregnancy remains uncomplicated, the next ultrasound is typically offered during the second trimester, when automatic details are visible.

If your baby's health needs to be monitored more closely, additional ultrasounds might be recommended.

\section{Here some reasons your health care provider might use fetal ultrasound:}

- Confirm the pregnancy and its location

Some fetuses develop outside of the uterus, in the fallopian tube. A fetal ultrasound can help your health care provider detect a pregnancy outside of the uterus (ectopic pregnancy).

- Determine your baby's gestational age

Knowing the baby's age can help your health care provider determine your due date and track various milestones throughout your pregnancy.

\section{- Confirm the number of babies}

If your health care provider suspects a multiple pregnancy, an ultrasound might be done to 


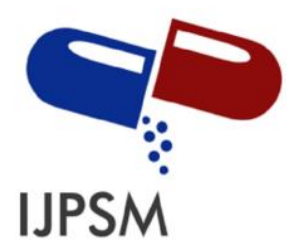

Sakshi Ahirwar et al, Int. Journal of Pharmaceutical Sciences and Medicine (IJPSM), Vol.6 Issue. 8, August- 2021, pg. 78-103

ISSN: 2519-9889

Impact Factor: 3.426

confirm the number of babies.

- Evaluate your baby's growth

Your health care provider can use ultrasound to determine whether your baby is growing at a normal rate. Ultrasound can be used to monitor your baby's movement, breathing and heart rate.

\section{- Identify the birth defects}

An ultrasound can help your health care provider screen for some birth defects.

\section{- Investigate complications}

If you're bleeding or having other complications, an ultrasound might help your health care provider determine the cause.

- Determine fetal position before delivery

Most babies are positioned headfirst by the end of the third trimester. That doesn't always happen, though. Ultrasound imaging can confirm the baby's presentation so that your health care provider can discuss options for delivery.

- Perform other prenatal tests

Your health care provider might use ultrasound to guide needle placement during certain prenatal tests, such as amniocentesis or chronic villus sampling.

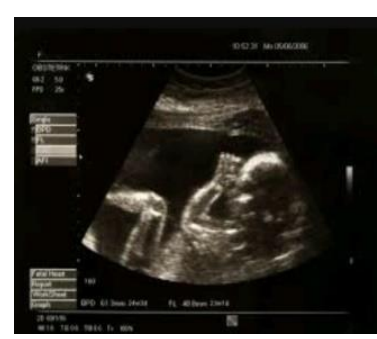

Figure: 16 Ultrasound

\section{COMPLICATIONS THAT CAN OCCUR DURING PREGNANCY INCLUDE:}

1. Anemia (low red blood cell count).

2. Birth defects (including brain damage, hearing loss, and blindness).

3. Gestational diabetes (diabetes that starts during pregnancy).

4. Heart failure.

5. Low birth weight.

6. Miscarriage (pregnancy loss).

7. Placenta previa (abnormally low placement of the placenta, partially or 


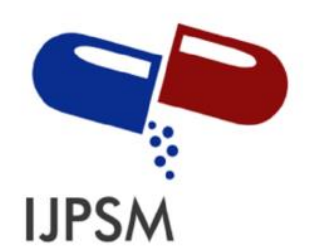

Sakshi Ahirwar et al, Int. Journal of Pharmaceutical Sciences and Medicine (IJPSM), Vol.6 Issue. 8, August- 2021, pg. 78-103

ISSN: 2519-9889

Impact Factor: 3.426

completely covering the cervix).

8. Placenta abruption (premature separation of the placenta from the uterine lining).

9. Preeclampsia (also called pregnancy- induced hypertension or toxemia).

10. Preterm labor (labor that begins before 37 weeks of pregnancy).

11. Still birth.

\section{DISEASES THAT INCREASES THE RISK OF PREGNANCY COMPLICATIONS:}

\section{Diabetes}

People with both type 1 and type 2 diabetes may experience complications during pregnancy. Poor control of diabetes can increases the chances of birth defects in the baby and can cause health concerns for the mother. This is called gestational diabetes.

\section{Sexually transmitted infections (STIs)}

You should be screened for STIs during you first prenatal visit. Women who have an STIs are very likely to transmit it to their baby. Depending on the infection, a baby born to a women with an STIs is at a higher risk for:

- Low birth weight

- Conjunctivitis

- Pneumonia

- Neurologic damage

- Blindness

- Deafness

- Acute hepatitis

- Chronic liver disease

There a risk that these infections can be passes from mother to child, but they can also cause serious complications during pregnancy. For example, an untreated gonorrhea infection can increases the risk of miscarriage, premature birth, and low birth weight.

\section{High blood pressure}

Pregnant women with chronic high blood pressure are at an increased risk for a low birth weight infant, preterm delivery, kidney damage, and preeclampsia during pregnancy.

\section{Polycystic ovary syndrome (PCOS)}

Polycystic ovary syndrome (PCOS) is a hormonal disorder that can cause irregular periods and your ovaries to not function properly. Pregnant women with PCOS have a higher risk of miscarriage, premature delivery, gestational diabetes, and preeclampsia. 


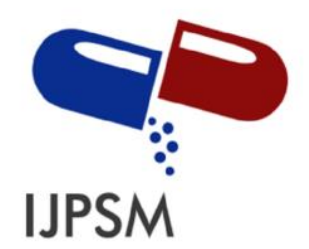

Sakshi Ahirwar et al, Int. Journal of Pharmaceutical Sciences and Medicine (IJPSM), Vol.6 Issue. 8, August- 2021, pg. 78-103

ISSN: 2519-9889

Impact Factor: 3.426

\section{Autoimmune disease}

Examples of autoimmune disease include conditions like multiple sclerosis (MS) and lupus. Women with an autoimmune disease may be at a risk for premature delivery or stillbirth. Additionally, some medication that's used to treat autoimmune diseases may harm the developing fetus.

\section{Kidney disease}

Women with kidney disease have an increased risk of miscarriage. Additionally, they should work with their doctor throughout their pregnancy to monitor their diet and medications.

\section{Thyroid disease}

Hyperthyroidism (overactive thyroid) or Hypothyroidism (under active thyroid) that isn't controlled can lead to heart failure or poor weight gain in the fetus as well as birth defects.

\section{Asthma}

Asthma that's not controlled can lead to an increased risk of poor fetal weight gain and premature delivery.

\section{Uterine fibroids}

While uterine fibroids can be relatively common, they can cause miscarriage and premature delivery in rare cases. A cesarean delivery may be required when a fibroid is blocking the birth canal.

\section{MISCARRIAGE}

Miscarriage, also known as spontaneous abortion and pregnancy loss, is the natural death of an embryo or fetus before it is able to survive independently. Some use the cutoff of 20 weeks of gestation, after which fetal death is known as a stillbirth.

The most common symptoms of a miscarriage is vaginal bleeding with or without pain. Sadness, anxiety, and guilt often occur afterwards. Tissue and clot like material may leave the uterus and pass through and out of the vagina. When a woman keeps having miscarriages, infertility is present.

About $80 \%$ of miscarriages occur in the first 12 weeks of pregnancy (the first trimester). The underlying cause in about half of cases involves chromosomal abnormalities. Miscarriage is the most common complication of the early pregnancy. In those under the age of 35 the risk is about $10 \%$ while is about $45 \%$ in those over the age of 40 . Risk begins 


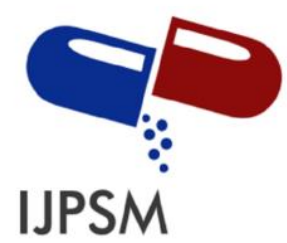

Sakshi Ahirwar et al, Int. Journal of Pharmaceutical Sciences and Medicine (IJPSM), Vol.6 Issue. 8, August- 2021, pg. 78-103

ISSN: 2519-9889

Impact Factor: 3.426

to increase around the age of 30. Diagnosis of a miscarriage may involve checking to see if the cervix is open or closed, testing blood levels of human chorionic gonadotropin (hCG), and an ultrasound.

\section{REFERENCES}

[1].Tortora Gerard J \& Derrickson Breyan, "Principle of anatomy \& physiology", Jone wiley \& sons inc, $11^{\text {th }}$ Edition 2006, Pg.no. 1105-1121,1124,1130-1132.

[2].Katzung Bertram G, Susan Masters B \& Trevor Anthony J, "Basic and clinical pharmacology" Tat McGraw Hill education private limited, $11^{\text {th }}$ Edition 2009, Pg.no. 1025-1029.

[3].Tripathi KD, "Essentials of Medical Pharmacology", Jaypee brothers medical publishers (P) LTD, $1^{\text {st }}$ Edition 1985; $6^{\text {th }}$ edition 2008,Pg.no. 908-914.

[4].Faber J, Thomburg K, "Placental physiology", 1 st ed. New York: Raven Press; 1983.

[5]."Definition of gravida". The Free Dictionary/ Medical Dictionary. Farlex, Inc. Retrieved 2008-01-17.

[6]."Nulliparous Definition”. MedicineNet.com. MedicineNet, Inc. Retrived 2008-01-17.

[7].“Pregnancy week by week”. Retrieved 2010 -07-28.

[8]."Pregnancy week by week symptoms”. Retrieved 2010-07-28.

[9]."Starting labour”. Pregnancy -bliss.co.uk. Retrieved 2009-01-14.

[10]."Lightening During Pregnancy as an early sign of labor". Giving Birth Naturally. Retrieved 2010-08-22.

[11].William J. Larsen 2001."Human embryology"” Edinburgh: Churchill livingstone.

[12].Reproductive Toxicology Center, Bethesda, Md-, at http://reprotox.org

[13]. Written by Helen Marshall, NetDoctor pharmacist 37

[14].Scott F. Gilbert \& Susan R, Singer (2000). "Development biology", Sunderland, Mass: Sinauer Associates.

[15].Mazza V, Falcinelli C, Paganelli S, et al. (june 2001). "Sonographic early fetal gender assignment: a longitudinal studies of pregnancies after in vitro fertilization". Ultrasound Obstet Gynecol 17 (6): 513-6.

[16].Carmichael SL, Shaw GM, et al, "National Birth Defects Prevention Study".

[17].B.B ARORA \& A.K Sabharwal, "Modern's abc of Biology", Morder publishers, Pg. no.510- 544.

[18].Alison MR, Poulsom R, Forbes S \& Wright NA. An introduction to stem cells J Pathol 2002; 197: 419-423.

[19].Sears, Martha; Sears, William The Breastfeeding Book. Little, Brown.

[20].Creel, S.R; Monfort, S.L; Wildt, D.E ;Waser, P.M. " Spontaneous lactation is an adaptive result of pseudopregnancy “. Nature 351. 